without altering the bioavailability of the compounds (Garnham, 1974). It is also clear that the appearance of the medication must be considered in the design of experiments and in the interpretation of results. Effects of colour have been shown in other conditions, green being preferred for anxiety and yellow for depression (Schapira et al., 1970).

The experimental design used in this study proved to be satisfactory for testing simple analgesics. There is reason to think that single-dose experiments may be more sensitive for the measurement of analgesic potency than studies based on multiple doses. Nuki et al. (1973) failed to show the effectiveness of pentazocine given regularly for one week to patients with rheumatoid arthritis, whereas in this study a single dose of pentazocine was clearly effective. If a compound produces its maximal effectiveness a few hours after ingestion its action is more likely to be detected by measurement made at that time rather than at the end of a week of multiple doses; the week must be compounded of many hours of little or no pain relief as well as the few hours of modest pain relief which these compounds provide.

The results of our three trials showed that in rheumatoid arthritis single doses of Distalgesic, Codis, and aspirin were about equally effective; pentazocine, paracetamol, and Ciba 44,328 were intermediate in effectiveness between these agents and placebo. Moertel et al. (1972), who studied patients with unresectable cancer, also found oral pentazocine $(50 \mathrm{mg})$ and paracetamol $(65 \mathrm{mg})$ similar and intermediate in effectiveness between aspirin $(650 \mathrm{mg})$ and placebo. Kantor et al. (1966) in a study of patients with postoperative pain or fractures also found aspirin $(600 \mathrm{mg})$ superior to pentazocine (50 mg).

The choice of a simple analgesic for patients with rheumatic conditions should be determined by the toxicity as well as the effectiveness of available medicines. Lack of toxicity is a particularly important feature in view of the rather modest effects of these drugs; they produce only slight to moderate pain relief, whereas placebo is not much less effective. Distalgesic and aspirin appear to be the first choices for effectiveness; Distalgesic may have the advantage of causing fewer side effects but no formal comparison has been made. There is little justification for using codeine with aspirin, and oral pentazocine cannot be recommended because of its side effects. Ciba 44,328 does not merit addition to the already long list of available pain killers.

I am indebted to Dr. H. Wykeham Balme and Dr. F. Dudley Hart, whose patients I studied; Miss Jane Scott for help with the conduct of the trials and the statistics; Mrs. Hazel Lane and Mrs. Ann Darby-Dowman for statistical advice; and Dista Products Ltd., Winthrop Laboratories, Reckitt and Colman Ltd., and Ciba Laboratories for supplies of analgesics.

\section{References}

Cromie, B. W. (1963). Lancet, 2, 994.

Garnham, J. C. (1974). Postgraduate Medical fournal, 50, 114.

Huskisson, E. C., and Hart, F. D. (1972 a). British Medical fournal, 4, 193. Huskisson, E. C., and Hart, F. D. (1972 b). Practitioner, 208, 248

Kantor, T. G., et al. (1966). Clinical Pharmacology and Therapeutics, 7, 447. Kendall, M. G. (1963). Rank Correlation Methods, 3rd edn. London, Griffin. Miller, R. G. (1966). Simultaneous Statistical Inference. New York, McGraw Hill.

Moertel, C. G., et al. (1972). New England fournal of Medicine, 286, 813.

Moertel, C. G., et al. (1972). New England fournal of Medicine,
Nuki, G., et al. (1973). Annals of Rheumatic Diseases, 32, 436.

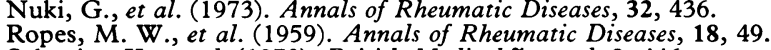

Schapira, K., et al. (1970). British Medical fournal, 2, 446.

Siegel, S. (1956). Non-Parametric Statistics for the Behavioral Sciences. New York, McGraw Hill.

Sunshine, A., et al. (1964). Clinical Pharmacology and Therapeutics, 5, 699.

\title{
Inverse Relation between Serum IgG Concentration and Glucose and Xylose Absorption in Zambian African Adults
}

\author{
G. C. COOK
}

British Medical fournal, 1974, 4, 200-201

\section{Summary}

In three separate investigations in Zambian African adults in Lusaka an inverse association has been shown between serum IgG concentration and either glucose absorption rate from the jejunum (from a $200-\mathrm{mM}$ solution) or xylose absorption (from a $25-\mathrm{g}$ oral load). In developing areas of the world, where serum IgG concentrations are often high, this finding may have widespread nutritional implications.

\section{Introduction}

Subclinical malabsorption of monosaccharides, shown by abnormal xylose absorption and flat oral glucose tolerance \footnotetext{
Department of Medicine, The University of Zambia, P.O. Box
RW 110, Lusaka, Zambia

G. C. COOK, M.D., F.R.C.P., Professor
}

curves, is common in African adults in tropical Africa. Morphological abnormalities of the jejunal mucosa and the presence of intestinal parasites do not usually explain this (Cook et al., 1969). Systemic bacterial infections, such as lobar pneumonia and pulmonary tuberculosis, have, however, been associated with a depression of glucose (Cook, 1971) and xylose (Cook, 1972) absorption in Zambian African patients. Furthermore, in two recent studies the jejunal absorption rate of glucose from a $200-\mathrm{mM}$ solution (Cook, 1973) and the weight of xylose excreted after a 25-g oral load (Cook, 1974) have been shown to be inversely related to serum $\gamma$-globulin concentration in separate groups of wellnourished Zambian African adults.

The present investigation was undertaken to determine whether carbohydrate malabsorption is associated with a high concentration of one or more of the serum immunoglobulin fractions. Serum concentrations of immunoglobulins IgG, $\operatorname{IgA}$, IgM, and IgD were determined in most of the subjects studied in two previous investigations (Cook, 1973, 1974), and correlations with glucose and xylose absorption were made. In an additional group of patients the relation between serum IgG concentration and xylose absorption was studied. 


\section{Patients and Methods}

Samples of serum from Zambian African adults studied in two previous investigations (Cook, 1973, 1974) were examined. The subjects were all well nourished. Those in the first investigation had no clinical evidence of an infection and those in the second had proven malaria. In the first study the jejunal absorption rate of glucose was determined by a double-lumen tube perfusion system (Cook, 1973). Serum samples from 13 of the 18 subjects were available, and their mean glucose absorption rate was $0.23 \mathrm{~g} / 30 \mathrm{~cm}$ of jejunum/ min (range $0.15-0.35 \mathrm{~g} / 30 \mathrm{~cm} / \mathrm{min}$ ). In the other study xylose absorption was determined (Cook, 1974). Serum samples from the 15 subjects were available, and their mean xylose excretion after a $25 \mathrm{-g}$ oral load was $6.2 \mathrm{~g} / 5 \mathrm{hr}$ (range 3.9-9.3 g/5hr). Mean immunoglobulin concentrations in the first investigation were; IgG $18.1 \mathrm{mg} / \mathrm{ml}$ (range 10-24), IgA $2.2 \mathrm{mg} / \mathrm{ml}(1 \cdot 2-3 \cdot 2)$, IgM $1.7 \mathrm{mg} / \mathrm{ml}(0.7-3.5)$, and IgD $0.10 \mathrm{mg} / \mathrm{ml}(0.01-0.36)$. In the second investigation, the mean concentrations were: IgG $17.7 \mathrm{mg} / \mathrm{ml}$ (14-24), IgA $2.0 \mathrm{mg} / \mathrm{ml}(1.2-3.7)$, IgM $1.6 \mathrm{mg} / \mathrm{ml}(0.4-3 \cdot 1)$, and $\operatorname{IgD} 0.06$ $\mathrm{mg} / \mathrm{ml}(0-0.18)$. Mean serum $\gamma$-globulin concentrations in the subjects in the two investigation were $2.1 \mathrm{~g} / 100 \mathrm{ml}(1.4-$ 2.9) and $2.2 \mathrm{~g} / 100 \mathrm{ml}(1 \cdot 7-3.0)$ respectively. Correlations between serum $\gamma$-globulin and IgG concentration in the first and second study were significant $(r=+0.82 ; \mathrm{P}<0.001$ and $r=+0.78 ; \mathrm{P}<0.001$ respectively).

In an additional investigation 17 adults with a serum IgG concentration of $15 \mathrm{mg} / \mathrm{ml}$ or less (mean $13 \mathrm{mg} / \mathrm{ml}$; range $7-15 \mathrm{mg} / \mathrm{ml}$ ) and 24 with serum IgG of $20 \mathrm{mg} / \mathrm{ml}$ or more (mean $27 \mathrm{mg} / \mathrm{ml}$; range $20-75 \mathrm{mg} / \mathrm{ml}$ ) were selected from 57 Zambian Africans who had had xylose absorption (from a 25-g oral load) and serum IgG concentration determined. The remainder of the 57 had IgG concentrations of 16-19 $\mathrm{mg} / \mathrm{ml}$. They were all inpatients at the University Teaching Hospital, Lusaka, and suffered from a wide range of diseases. Eleven patients with megaloblastic anaemia due to folate depletion, which is known to be associated with significantly low xylose excretion after an oral load (Foy and Kondi, 1971; G. C. Cook, unpublished observation), had previously been excluded from the investigation. The patient with an IgG concentration of $75 \mathrm{mg} / \mathrm{ml}$ had myelomatosis, and his xylose excretion was $4.8 \mathrm{~g} / 5 \mathrm{hr}$. Mean xylose excretion was $6.9 \mathrm{~g} / 5 \mathrm{hr}$ (range $4.3-10.7$ ) and $5.4 \mathrm{~g} /$ $5 \mathrm{hr}$ (range 1.5-9.1) in the patients with low and high IgG concentrations respectively. Mean serum urea in 33 of these patients (Cook, 1972) was $27 \mathrm{mg} / 100 \mathrm{ml}$ (range 12-46).

Serum immunoglobulin concentrations were determined using immunodiffusion plates (Meloy Laboratories Inc., Springfield, Virginia, U.S.A.), and standard curves using serum samples from the same laboratory were constructed. All determinations were made at the same time, and most were repeated on another occasion.

\section{Results}

In the subjects in the first investigation (Cook, 1973) the correlation between serum IgG concentration and glucose absorption rate was inversely significant $(r=-0.646$; d.f. $=11 ; \mathrm{P}<0.02 ; y=0.407-0.010 x)$. In the subjects in the second investigation (Cook, 1974) the correlation between serum IgG concentration and weight of xylose excreted was inversely significant $(r=-0.725$; d.f. $=13 ; \mathrm{P}<0.01 ; y$ $=13 \cdot 307-0 \cdot 399 x)$. None of the correlations between glucose absorption rate or weight of xylose excreted and serum IgA, IgM, or IgD concentration were significant.

In the additional investigation the mean weight of xylose excreted in the group with a high serum IgG concentration was significantly lower than in the other group (Student's $t$ test $):(t=2.73$; d.f. $=39 ; \mathrm{P}<0.01)$. These results suggest that the slope of the curve which inversely associates xylose excretion with serum IgG is steepest between IgG values of 10 and $20 \mathrm{mg} / \mathrm{ml}$ and levels out at higher concentrations. In the 15 patients with IgG concentrations of 20$25 \mathrm{mg} / \mathrm{ml}$ and the nine with IgG of $>25 \mathrm{mg} / \mathrm{ml}$ mean xylose excretion was $5.6 \mathrm{~g} / 5 \mathrm{hr}$ and $5.1 \mathrm{~g} / 5 \mathrm{hr}$ respectively.

\section{Discussion}

An inverse association between serum IgG concentration and rate of glucose absorption from the jejunum (from a $200-\mathrm{mM}$ solution) and xylose absorption (from a 25-g oral load) has been shown. When properly carried out the xylose absorption test gives a good indication of overall absorption from the small intestine. Glucose and xylose probably share the same jejunal transfer system (Crane, 1968). The mechanism underlying the inverse relationship is unknown. High serum $\gamma$-globulin concentration has, however, been significantly associated with impaired blood/cerebrospinal fluid transfer of glucose (D. W. Thomas, personal communication) and decreased renal tubular transport of $\mathrm{H}^{+}$(Smith, 1970). It seems possible that a general effect of high serum IgG concentration on membrane transfer may exist.

Most indigenous people in the developing countries of Africa and Asia have a raised serum $\gamma$-globulin concentration, which is largely associated with malaria and is due predominantly to a high IgG concentration (Rowe, 1972). As most of them live largely on a staple diet of carbohydrate which has a glucose base the present results may have widespread nutritional implications. The results may also explain part of the weight loss in other conditions associated with a high IgG concentration.

Falaiye (1971) has indicated that in Nigeria subclinical malabsorption is closely related to a low serum albumin concentration. The present investigation suggests, however, that systemic infections are more important than marginal malnutrition in the pathogenesis of carbohydrate malabsorption. Attempts to improve the nutritional status of rural Africans must seriously take into account the elimination of chronic systemic infections, especially malaria.

I thank Dr. K. O. Lewis for his help with the serum immunoglobulin determinations and the Reverend W. H. Woodhouse for generous financial support.

\section{References}

Cook, G. C. (1971). Gut, 12, 1001.

Cook, G. C. (1972). American fournal of Clinical Nutrition, 25, 490.

Cook, G. C. (1973). Nature, 241, 284

Cook, G. C. (1974). Transactions of the Royal Society of Tropical Medicine and Hygiene. In press.

Cook, G. C., Kajubi, S. K., and Lee, F. D. (1969). Fournal of Pathology, 98, 157.

Crane, R. K. (1968). In Handbook of Physiology, section 6, vol. 3, p. 1344. Washington, American Physiological Society

Falaiye, J. M. (1971). British Medical fournal, 4, 454.

Foy, H. and Kondi, A. (1971). In Tropical Sprue and Megaloblastic Anaemia. p. 261. Edinburgh and London, Churchill Livingstone.

Smith, L. H. (1970). In Harrison's Principles of Internal Medicine 6th edn., 592. New York, MacGraw-Hill.

Rowe, D. S. (1972). Lancet, 2, 1232. 